\title{
RESEARCH PAPER \\ Amino acid, mineral, condensed tannin, and other chemical contents of olive leaves (Olea europaea L.) processed via solid-state fermentation using selected Aspergillus niger strains
}

\author{
Aydin Altop ${ }^{1}$, Isa Coskun², Gokhan Filik², Altug Kucukgul ${ }^{3}$, Yeliz Genc \\ Bekiroglu ${ }^{4}$, Huseyin Cayan², Emrah Gungor', Ahmet Sahin², and Guray Erener ${ }^{1}$ \\ ${ }^{1}$ Ondokuz Mayis University, Agricultural Faculty, Animal Science Department, Samsun, Turkey \\ ${ }^{2}$ Kirsehir Ahi Evran University, Agricultural Faculty, Animal Science Department, Kirsehir, Turkey \\ ${ }^{3}$ Mustafa Kemal University, Faculty of Veterinary Medicine, Hatay, Turkey \\ ${ }^{4}$ Ondokuz Mayis University, Bafra Vocational School, Samsun, Turkey
}

\begin{abstract}
Altop, I. Coskun, G. Filik, A. Kucukgul, Y.G. Bekiroglu, H. Cayan, E. Gungor, A. Sahin and G. Erener. 2018. Amino acids, minerals, condensed tannin, and other chemical contents in olive leaves (Olea europaea L.) processed via solid-state fermentation using selected Aspergillus niger strains. Cien. Inv. Agr. 45(3): 220-230. The present study aimed to examine the effects of solid-state fermentation (SSF) using selective A. niger strains on the amino acid, mineral, condensed tannin, and other chemical contents of olive leaves. The dried samples were divided into nonfermented $(\mathrm{C})$ and fermented $(\mathrm{F})$ olive leaves, and the latter were fermented by the following A. niger strains: $\operatorname{ATCC}^{\circledR} 9142^{\mathrm{TM}}(\mathrm{F} 1), \mathrm{ATCC}^{\circledR} 200345^{\mathrm{TM}}(\mathrm{F} 2), \mathrm{ATCC}^{\circledR} 52172^{\mathrm{TM}}(\mathrm{F} 3)$, and $\mathrm{ATCC}^{\circledR} 201572^{\mathrm{TM}}$ (F4), with three replicates for each treatment. Group F4 presented the best results, although all fermented groups generally presented higher performance than $\mathrm{C}$. The total content of amino acids of the fermented olive leaves increased by $68-209 \%$ in comparison to that of $C$, while the cellulose content of the fermented olive leaves decreased by $7-25 \%$. The ash, crude protein $(\mathrm{CP})$, and ether extract $(\mathrm{EE})$ contents increased after fermentation, but the crude fiber (CF) and nitrogen-free extract (NFE) contents decreased. The content of neutral detergent fiber (NDF) did not change, but acid detergent fiber (ADF) varied among the groups. The starch and sugar contents of all fermented groups except F1 also decreased compared to those of C. The mineral contents increased in all fermented groups, and the condensed tannin content varied according to the $A$. niger strain used. Thus, olive leaves fermented with different $A$. niger strains, especially F4, seem to have considerable potential as ruminant feed, as they are enriched with amino acids and minerals and have an improved chemical composition. However, these results should be supported and validated by animal experiments.
\end{abstract}

Key words: Fermentation, fungus, nutritional quality, Olea.

\section{Introduction}

The rapid population growth and development of the livestock sector have increased the demand

Received Oct 24, 2017. Accepted Sep 24, 2018.

Corresponding author: aaltop@omu.edu.tr for protein-enriched feed. According to some researchers, in the future, it will not be possible to meet this demand only by using current forage and commercial grain feeds (Xie et al., 2016). Thus, it is necessary to find new alternative feeds. Currently, millions of tons of byproducts or waste are created by agricultural industries every year, 
and these products can be used in animal nutrition (Sayehban et al., 2015; Sayehban et al., 2016; Xie et al., 2016; Sateri et al., 2017). Olive leaves, for example, which are a byproduct from agricultural industries, are collected during pruning and oil extraction (Martín-García et al., 2003; Martín-García and Molina-Alcaide, 2008), and every year, $10 \%$ of the total weight of harvested olives are generally leaves. Previous studies have demonstrated that adding raw olive leaves to diets did not affect the performance of sheep, goats, lactating cows, and pigs (Paiva-Martins et al., 2009). These results were mostly due to the low nutrition value (low protein and cellulose components) of the leaves and to some components (tannin, nonstarch polysaccharides, etc.) of the leaves that have a negative effect on the animals (Martín-García et al., 2003). Although different methodologies, such as using treatments with hydrous ammonia, drying (Martín-García and Molina-Alcaide, 2008), urea-ammonia processing, and using white saprophyte fungi to break down the lignin-carbohydrate complex (Dermeche et al., 2013), have been applied to improve the abovementioned factors, satisfactory results have not been obtained.

Solid-state fermentation (SSF) is an important tool for producing biologic materials that positively affect health. Previous studies have demonstrated that the protein quality of both feedstuffs (Mathivanan et al., 2006) and agricultural industry waste (Zhang et al., 2012) could be improved by using SSF to break down non-starch polysaccharides (NSP) that could then be transformed into glucose, thus eliminating the anti-nutritional components. In many studies using fungi as the microbial inoculants, $A$. niger showed a rather strong ability to produce enzymes, such as hemicellulase, hydrolase, pectinase, protease, amylase, lipase, and tannase, during fermentation, thereby improving the nutritional composition of the fermented products (Yao and Nokes, 2014).

Although some studies have considered the use of olive leaves in breeding stock feed (Pertínez et al., 2000; Martín-García et al., 2003; Cayan and Erener, 2015), the number of studies related to the nutritional and chemical improvement of dried olive leaves fermented by $A$. niger is rather limited. In fact, the effect of using $A$. niger as the microbial inoculant in SSF on the nutrient (CF, ADF, NDF, EE, etc.), macro and micro element, starch, and sugar contents of olive leaves have not been demonstrated so far. In addition, there is no information on the improvement of the nutritional value of olive leaves by using selected $A$. niger strains with certain characteristics, such as single cell protein, tannase, and cellulase production ability. Thus, the present study determined the chemical content and nutrient and mineral composition of olive leaves fermented by selected $A$. niger strains, aiming to highlight the implications of utilizing fermented olive leaves in animal nutrition.

\section{Materials and methods}

\section{Olive leaf procurement and storage}

The leaves were collected from an olive grove in Aydin province, Turkey (37045'32" N; 27 $7^{\circ} 45^{\prime} 11^{\prime \prime}$ E) in September 2015, air dried in the shade at $30^{\circ} \mathrm{C}$ and $15-20 \%$ relative humidity for three days, and stored in shelters (for protection against insects, light, mice, etc.).

\section{Microorganisms}

All microorganisms used in this study were obtained from the American Type Culture Collection (ATCC, Wesel, Germany). A. niger strains were chosen as the microbial inoculum because of their potential to degrade cellulosic materials, tannins, and tannin-protein complexes, based on the ATCC guide. The microorganisms used were $\mathrm{ATCC}^{\circledR} 9142^{\mathrm{TM}}, \mathrm{ATCC}^{\circledR} 200345^{\mathrm{TM}}$, $\mathrm{ATCC}^{\circledR} 52172^{\mathrm{TM}}$, and $\mathrm{ATCC}^{\circledR} 201572^{\mathrm{TM}}$. 


\section{Culture medium and culture conditions}

The A. niger strains obtained from ATCC were incubated on potato dextrose agar (PDA; Oxoid Ltd., Basingstoke, UK) at $28{ }^{\circ} \mathrm{C}$ for seven days, according to the agar plate technique. After incubation, the spores were harvested by turning the plate upside down and gently hitting the top, counted in a hemocytometer using the Fuchs-Rosenthal technique, and inoculated into the olive leaves on the same day (Zhang et al., 2012).

\section{Solid-state fermentation preparation}

Before fermentation, the dry olive leaves were ground in a 2-mm sieve (ZM200; RETSCH, Haan, Germany) and autoclaved at $121^{\circ} \mathrm{C}$ for 15 min. After sterilization, the leaves were divided into two groups: fermented and nonfermented. The olive leaves subjected to fermentation were placed in a $1 \mathrm{~kg}$ of solid stock (olive leaves: wheat bran:corn cob $=8: 1: 0.5)$ with 1.6 $\mathrm{L}$ of nutritional salt (glucose:urea:(NH4) $\mathrm{SO}_{4}$ :peptone: $\left.\mathrm{KH}_{2} \mathrm{PO}_{4}: \mathrm{MgSO}_{4} \cdot 7 \mathrm{H}_{2} \mathrm{O}=4: 2: 6: 1: 4: 1\right)$. The $\mathrm{pH}$ of the fermentation environment was calibrated to 5 using $1 \mathrm{~N} \mathrm{NaOH}$ and $\mathrm{HCl}$. The starting relative humidity was $60 \%$, and after adding the nutritional salt, $1.4 \times 10^{6} \mathrm{~A}$. niger spores per $\mathrm{kg}$ of solid environment were put inside a sterile cabin at $28-30{ }^{\circ} \mathrm{C}$. Because $A$. niger is a microaerobic organism, it is able to grow and develop even if it is left in a closed environment (David et al., 2003). Thus, after incubation, the fermented olive leaves were placed in plastic containers, gently pressed, and left for $48 \mathrm{~h}$ at the same temperature as incubation. At the end of this period, the olive leaves were spread on top of a polythene sheet in a room at $30-40{ }^{\circ} \mathrm{C}$ for six days until reaching approximately $90 \%$ dry matter. Then, the leaves were broken into $0.15 \mathrm{~mm}$ pieces. After the fermentation period, the $A$. niger strains were exposed to $60^{\circ} \mathrm{C}$ for $48 \mathrm{~h}$ to become inactive.

\section{Chemical composition analyses}

Ash (method 942.05), CP (method 976.06), ether extract (EE, method 920.29), and crude fiber (CF, method 973.18) were determined according to the Association of Official Analytical Chemists (AOAC, 1990) methods before and after SSF. The neutral detergent fiber (NDF) and acid detergent fiber (ADF) analyses were conducted according to Van Soest et al. (1991) using the ANKOM ${ }^{200 / 220}$ fiber analyzer (ANKOM Corporation ${ }^{\circledR}$ Technology, Fairport, NY, USA). The leaf starch content was determined according to the polarimetric method (method TS ISO 6493), while the sugar analysis was conducted according to the LuffSchoorl method (TS 12732). Each sample was measured three times, and the average value of each measurement was determined. Metabolic energy (ME) and the nitrogen-free extract (NFE) content were calculated according to Moran and Jones $(1992)\left[\mathrm{ME}^{1}\left(\mathrm{kcal} \mathrm{kg}^{-1}\right.\right.$ dry matter $\left.(\mathrm{DM})\right)=$ $18.22 \% \mathrm{CP}+11.01 \% \mathrm{CF}+63.85 \% \mathrm{EE}+41.43 \% \mathrm{NFE}$ $-216,93 ; \mathrm{ME}^{2}\left(\mathrm{kcal} \mathrm{kg}^{-1} \mathrm{DM}\right)=2677+52.18 \% \mathrm{CP}$ $-62.40 \% \mathrm{EE}-41.66 \% \mathrm{Ash}-23.21 \% \mathrm{CF}$; NFE $=$ $\mathrm{DM}-(\mathrm{Ash}+\mathrm{CP}+\mathrm{EE}+\mathrm{CF})]$ and Robinson et al. (2004) $\left[\mathrm{ME}^{3}\left(\mathrm{kcal} \mathrm{kg}^{-1} \mathrm{DM}\right)=3053+2.02 \% \mathrm{CP}+\right.$ $66.90 \% \mathrm{EE}-17.30 \% \mathrm{Ash}-29.63 \% \mathrm{CF}]$, respectively.

\section{Amino acid analysis}

The amino acid composition of the fermented and unfermented olive leaves were analyzed according to Dimova (2003). For this purpose, the homogenized samples $(0.1-1.0 \mathrm{~g})$ were placed in $50-\mathrm{mL}$ closed analysis bottles; $20 \mathrm{~mL}$ of a $6 \mathrm{~N}$ hydrochloric acid solution was then added to each sample, followed by nitrogen gas, and the bottle was firmly closed. After hydrolysis in a drying oven for $24 \mathrm{~h}$ at $110{ }^{\circ} \mathrm{C}$, the samples were brought to room temperature and filtered through filter paper; $0.2 \mathrm{~mL}$ of the filtrate was then passed through a test tube and evaporated under nitrogen gas at $50{ }^{\circ} \mathrm{C}$. This evaporation process was repeated after adding $0.5 \mathrm{~mL}$ of acetonitrile. 
Approximately $0.5 \mathrm{~mL}$ of acetonitrile:methano 1:triethylamine and $0.1 \mathrm{~mL}$ of a derivatization solution were added to the residue inside the test tube, which was derivatized for $30 \mathrm{~min}$ in a drying oven at $40^{\circ} \mathrm{C}$. After evaporation under nitrogen gas at $40{ }^{\circ} \mathrm{C}, 0.2 \mathrm{~mL}$ of acetonitrile was added, and the residue was re-evaporated under nitrogen gas. Then, $5 \mathrm{~mL}$ of a $0.02 \mathrm{M}$ ammonium acetate solution was added, and after filtering through a $0.2-\mu \mathrm{m}$ filter, ultrafast liquid chromatography (UFLC) was conducted according to the conditions and profile presented in Tables 1 and 2 .

Table 1. Ultrafast liquid chromatography conditions.

\begin{tabular}{ll}
\hline Mobile Phase A & $\begin{array}{l}0.78 \mathrm{~g} \text { sodium dihydrogen } \\
\text { phosphate dihydrate and } 0.88 \mathrm{~g} \\
\text { disodium hydrogen phosphate } \\
\text { dihydrate were weighted and } \\
\text { added to 1 L deionized water. } \\
\text { This solution was filtered after } \\
\text { the } \mathrm{pH} \text { value was calibrated to } \\
6.8-6.9\end{array}$ \\
& Acetonitrile \\
& $40^{\circ} \mathrm{C}$ \\
Mobile Phase B & $\mathrm{UV}$ \\
Column Temperature & $254 \mathrm{~nm}$ \\
Detector & $10 \mu \mathrm{L}$ \\
Wave Length & $1 \mathrm{~mL} \mathrm{~min}{ }^{-1}$ \\
Injection Volume & Agilent, Eclipse XDB-C18; $5 \mu \mathrm{m}$, \\
Flow Speed & $4 \times 6 \times 150 \mathrm{~mm}$ \\
Column &
\end{tabular}

Table 2. Gradient profile used for the separation of amino acids.

\begin{tabular}{lcc}
\hline Time (minutes) & $\begin{array}{c}\text { Mobile Phase } \\
\text { A }(\%)\end{array}$ & $\begin{array}{c}\text { Mobile Phase B } \\
(\%)\end{array}$ \\
\hline 0.01 & 100 & 0 \\
13.00 & 85 & 15 \\
22.00 & 75 & 25 \\
26.00 & 70 & 30 \\
28.00 & 40 & 60 \\
38.01 & 100 & 0 \\
\hline
\end{tabular}

\section{Analyses of macro and micro minerals}

The contents of micro and macro minerals in the olive leaves before and after SSF were determined according to the AOAC (1990) method. Briefly, the samples were dried in the oven for $48 \mathrm{~h}$ at $65^{\circ} \mathrm{C}$, and $5 \mathrm{~g}$ of each sample was then mixed with $6 \mathrm{~mL}$ of $65 \%$ nitric $\mathrm{HClO}_{4}$ and left to stand overnight. After
$24 \mathrm{~h}$, the samples were heated at $100-150^{\circ} \mathrm{C}$ until they turned light yellow, cooled down, placed in $50-\mathrm{mL}$ flasks and diluted by adding distilled water to the meniscus line. The macro and micro mineral contents of the diluted samples were quantified by inductively coupled plasma-mass spectrometry (ICP-MS) on a PerkinElmer Elan DRCe instrument (PerkinElmer SCIEX, Shelton, CT, USA).

\section{Determination of condensed tannins}

Changes in the amount of condensed tannins after SSF were determined using the butanol-HCl method (Makkar et al., 1995). In brief, the samples (0.01 g) were mixed with $6 \mathrm{~mL}$ of an n-butanol: $\mathrm{HCl}: \mathrm{FeSO}_{4}$ solution (95:5:0.05), boiled in a condenser unit for $1 \mathrm{~h}$, and then rapidly cooled down in iced water. The absorbance values were determined by a spectrometer (Genesys 10S UV-Vis, USA) at $550 \mathrm{~nm}$.

\section{Statistical analyses}

One-way analysis of variance (ANOVA) followed by Duncan's multiple comparison tests were performed in SPSS 21.0 for Windows (IBM Corporation, Armonk, NY, USA) to determine whether the differences found between the mean values of all variables (except minerals) in both groups were significant $(\mathrm{P}<0.05)$.

\section{Results}

The changes in the chemical composition of olive leaves after SSF are presented in Table 3. The ash, $\mathrm{CP}$, and $\mathrm{EE}$ contents increased in the fermented leaves, while the amount of $\mathrm{CF}$ and NFE decreased compared to those in $\mathrm{C}(\mathrm{P}<0.01)$. In addition, $\mathrm{ADF}$ in the F3 group was not significantly different from that in the control, while NDF only decreased in this group $(\mathrm{P}<0.01)$. The highest increase was observed in $\mathrm{CP}$ in the $\mathrm{F} 4$ group (164\%), while the $\mathrm{CF}$ and NFE contents were the lowest in this group. In addition, the ME values of the fermented olive 
leaves decreased for all fermented groups when the first equation was used, but an increase in ME was observed when it was calculated using the second and third equations $(\mathrm{P}<0.01)$.

Figure 1 presents the changes observed in the olive leaf starch and sugar contents after SSF. According to these results, both the starch and sugar contents decreased in all groups compared to those in $\mathrm{C}(\mathrm{P}<0.01)$.

In addition, all $A$. niger strains positively altered the amino acid composition of the olive leaves after fermentation but to different extents (Table 4). In general, the highest amino acid contents were observed in F4, while the lowest were observed in $\mathrm{C}(\mathrm{P}<0.01)$.

The changes in the contents of some macro minerals in the fermented olive leaves are presented in Figure 2. Generally, the mineral levels increased in all fermented groups compared to those in C. The highest increase in phosphorus and calcium was observed in F3.

The changes in the micro mineral contents of the fermented olive leaves were similar to those observed for the macro minerals (Figure 3). The iron content increased in all fermented groups compared to that of $\mathrm{C}$, although the highest

Table 3. Average chemical composition (in percentage, \%) of the fermented and unfermented olive leaves (on a dry matter basis, DM).

\begin{tabular}{lccccccc}
\hline Chemical & C & F1 & F2 & F3 & F4 & SEM & P value \\
\hline $\mathrm{CP}, \%$ & $12.92^{\mathrm{e}}$ & $30.38^{\mathrm{d}}$ & $32.15^{\mathrm{b}}$ & $31.92^{\mathrm{c}}$ & $33.51^{\mathrm{a}}$ & 2.06 & $<0.001$ \\
$\mathrm{EE}, \%$ & $2.39^{\mathrm{b}}$ & $3.27^{\mathrm{a}}$ & $3.32^{\mathrm{a}}$ & $3.24^{\mathrm{a}}$ & $3.21^{\mathrm{a}}$ & 0.95 & $<0.001$ \\
$\mathrm{Ash}, \%$ & $6.41^{\mathrm{d}}$ & $11.12^{\mathrm{c}}$ & $11.82^{\mathrm{b}}$ & $11.76^{\mathrm{b}}$ & $12.91^{\mathrm{a}}$ & 0.61 & $<0.001$ \\
$\mathrm{NFE}, \%$ & $50.45^{\mathrm{a}}$ & $31.99^{\mathrm{b}}$ & $31.48^{\mathrm{c}}$ & $31.89^{\mathrm{b}}$ & $28.69^{\mathrm{d}}$ & 2.10 & $<0.001$ \\
$\mathrm{CF}, \%$ & $27.83^{\mathrm{a}}$ & $23.24^{\mathrm{b}}$ & $21.24^{\mathrm{d}}$ & $21.19^{\mathrm{d}}$ & $21.68^{\mathrm{c}}$ & 0.67 & $<0.001$ \\
$\mathrm{NDF}, \%$ & $38.81^{\mathrm{b}}$ & $39.34^{\mathrm{b}}$ & $40.92^{\mathrm{a}}$ & $37.51^{\mathrm{c}}$ & $40.90^{\mathrm{a}}$ & 0.38 & 0.001 \\
$\mathrm{ADF}, \%$ & $26.95^{\mathrm{c}}$ & $28.43^{\mathrm{b}}$ & $29.30^{\mathrm{b}}$ & $26.97^{\mathrm{c}}$ & $33.74^{\mathrm{a}}$ & 0.68 & $<0.001$ \\
$\mathrm{ME}$ & $2567.67^{\mathrm{a}}$ & $2127.01^{\mathrm{b}}$ & $2118.80^{\mathrm{b}}$ & $2126.11^{\mathrm{b}}$ & $2025.58^{\mathrm{c}}$ & 51.11 & $<0.001$ \\
$\mathrm{ME}^{2}(\mathrm{kcal} / \mathrm{kg})$ & $2288.82^{\mathrm{d}}$ & $3055.63^{\mathrm{c}}$ & $3162.11^{\mathrm{b}}$ & $3158.49^{\mathrm{b}}$ & $3184.54^{\mathrm{a}}$ & 91.81 & $<0.001$ \\
$\mathrm{ME}^{3}(\mathrm{kcal} / \mathrm{kg})$ & $2310.70^{\mathrm{d}}$ & $2462.26^{\mathrm{c}}$ & $2515.90^{\mathrm{a}}$ & $2512.64^{\mathrm{a}}$ & $2479.16^{\mathrm{b}}$ & 20.20 & $<0.001$ \\
\hline $\mathrm{Difer}$ & & & & & & & \\
\hline
\end{tabular}

Different superscripts in the same row indicate significant differences $(\mathrm{P}<0.05)$
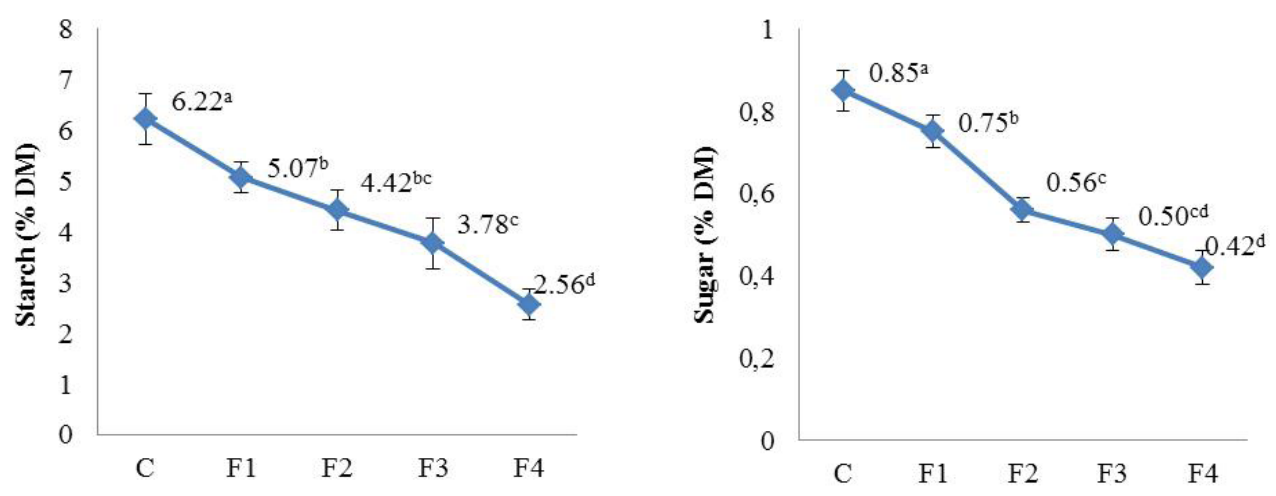

Figure 1. Changes in the olive leaf sugar (left panel) and starch (right panel) contents on a dry matter (DM) basis after solid-state fermentation (SSF). C, unfermented olive leaves; F1, strain ATCC ${ }^{\circledR} 9142^{\mathrm{TM}}$; F2, strain ATCC ${ }^{\circledR} 200345^{\mathrm{TM}}$; F3, strain $\mathrm{ATCC}^{\circledR} 52172^{\mathrm{TM}}$; and F4, strain $\mathrm{ATCC}^{\circledR} 201572^{\mathrm{TM}}$. Values with different superscripts differ significantly $(\mathrm{P}<0.05)$. 
Table 4. Changes in the olive leaf amino acid contents after solid state fermentation.

\begin{tabular}{|c|c|c|c|c|c|c|c|}
\hline & $\mathrm{C}$ & F1 & $\mathrm{F} 2$ & F3 & F4 & SEM & $P$ value \\
\hline Aspartic Acid & $511.04^{\mathrm{e}}$ & $1876.72^{\mathrm{d}}$ & $2077.76^{\mathrm{c}}$ & $2238.42^{\mathrm{b}}$ & $2405.22^{\mathrm{a}}$ & 181.57 & $<0.001$ \\
\hline Glutamic Acid & $769.72^{\mathrm{d}}$ & $1741.45^{\mathrm{c}}$ & $1866.64^{\mathrm{b}}$ & $1957.26^{\mathrm{b}}$ & $2632.96^{\mathrm{a}}$ & 160.19 & $<0.001$ \\
\hline Serine & $182.67^{\mathrm{d}}$ & $377.22^{\mathrm{c}}$ & $386.60^{\circ}$ & $499.78^{b}$ & $1165.40^{\mathrm{a}}$ & 90.18 & $<0.001$ \\
\hline Glycine & $328.90^{\mathrm{e}}$ & $474.54^{c}$ & $465.02^{\mathrm{d}}$ & $529.15^{\mathrm{b}}$ & $1035.63^{\mathrm{a}}$ & 65.11 & $<0.001$ \\
\hline Histidine & $32.73^{\mathrm{e}}$ & $73.14^{\mathrm{d}}$ & $101.45^{\mathrm{c}}$ & $145.75^{\mathrm{b}}$ & $298.99^{\mathrm{a}}$ & 24.67 & $<0.001$ \\
\hline Arginine & $116.68^{d}$ & $266.14^{\mathrm{b}}$ & $168.35^{\mathrm{c}}$ & $151.73^{\mathrm{c}}$ & $734.74^{\mathrm{a}}$ & 61.25 & $<0.001$ \\
\hline Threonine & $197.45^{\mathrm{e}}$ & $342.02^{\mathrm{d}}$ & $367.95^{\mathrm{c}}$ & $468.78^{\mathrm{b}}$ & $1446.57^{\mathrm{a}}$ & 120.15 & $<0.001$ \\
\hline Alanine & $405.45^{\mathrm{d}}$ & $541.08^{c}$ & $588.40^{\mathrm{b}}$ & $641.73^{\mathrm{a}}$ & $652.68^{\mathrm{a}}$ & 23.99 & $<0.001$ \\
\hline Proline & $441.35^{d}$ & $516.33^{c}$ & $497.92^{c}$ & $562.32^{\mathrm{b}}$ & $1094.15^{\mathrm{a}}$ & 63.96 & $<0.001$ \\
\hline Tyrosine & $269.25^{\mathrm{e}}$ & $383.81^{\mathrm{d}}$ & $415.66^{c}$ & $435.07^{\mathrm{b}}$ & $755.73^{\mathrm{a}}$ & 43.42 & $<0.001$ \\
\hline Valine & $433.96^{\mathrm{e}}$ & $477.84^{\mathrm{d}}$ & $518.76^{\mathrm{c}}$ & $572.11^{\mathrm{b}}$ & $758.27^{\mathrm{a}}$ & 30.14 & $<0.001$ \\
\hline Methionine & $69.69^{\mathrm{e}}$ & $121.52^{\mathrm{d}}$ & $137.09^{\mathrm{c}}$ & $155.00^{\mathrm{b}}$ & $256.37^{\mathrm{a}}$ & 16.38 & $<0.001$ \\
\hline Isoleucine & $409.68^{\mathrm{e}}$ & $486.64^{d}$ & $514.92^{\mathrm{c}}$ & $583.53^{\mathrm{b}}$ & $597.33^{\mathrm{a}}$ & 18.29 & $<0.001$ \\
\hline Leucine & $622.43^{\mathrm{e}}$ & $719.24^{\mathrm{d}}$ & $731.52^{\mathrm{c}}$ & $807.05^{\mathrm{b}}$ & $1428.76^{\mathrm{a}}$ & 77.38 & $<0.001$ \\
\hline Phenylalanine & $380.11^{\mathrm{e}}$ & $425.05^{\mathrm{d}}$ & $445.83^{c}$ & $494.35^{\mathrm{b}}$ & $930.67^{\mathrm{a}}$ & 53.76 & $<0.001$ \\
\hline Lysine & $206.42^{\mathrm{c}}$ & $387.11^{\mathrm{a}}$ & $387.70^{\mathrm{a}}$ & $368.18^{\mathrm{b}}$ & $161.58^{d}$ & 26.14 & $<0.001$ \\
\hline Tryptophan & $158.38^{\mathrm{d}}$ & $168.26^{\mathrm{d}}$ & $381.12^{\mathrm{b}}$ & $230.04^{c}$ & $920.49^{\mathrm{a}}$ & 76.39 & $<0.001$ \\
\hline Total* & $5535.85^{\mathrm{e}}$ & $9378.08^{d}$ & $10052.65^{\mathrm{c}}$ & $10840.21^{\mathrm{b}}$ & $17275.47^{\mathrm{a}}$ & 1015.04 & $<0.001$ \\
\hline
\end{tabular}

Values are mg $100 \mathrm{~g}^{-1}$ dry matter (DM)

Different superscripts in the same row indicate significant differences $(P<0.05)$

SEM: Standard error of the mean

*Without cysteine

C, unfermented olive leaves; F1, strain $\mathrm{ATCC}^{\circledR} 9142^{\mathrm{TM}}$; F2, strain $\mathrm{ATCC}^{\circledR} 200345^{\mathrm{TM}}$; F3, strain $\mathrm{ATCC}^{\circledR}$ 52172 ${ }^{\mathrm{TM}}$; and F4, strain $\mathrm{ATCC}^{\circledR} 201572^{\mathrm{TM}}$

increase was observed in F4. The levels of manganese, copper, and zinc did not change among the groups, and boron increased in all groups after fermentation.

The condensed tannin content of the fermented and unfermented olive leaves are presented in Figure 4. The values in the control group were lower than in the fermented groups. The highest condensed tannin content among the fermented groups was found in $\mathrm{F} 2$, while the lowest was found in $\mathrm{F} 4(\mathrm{P}<0.01)$.

\section{Discussion}

The results of this study revealed that the $A$. niger strains used in SSF had a key role in the changes observed in the nutritional value of the olive leaves. Although similar to the results obtained by Xie et al. (2016), the present results also revealed increases in the amino acids and protein contents and changes in the condensed tannin content. These changes might be explained by several factors, such as the origin of $A$. niger, enzyme production capability, amount of inoculum, fermentation period, fermentation conditions, pretreatment, plant origin, variety of olive trees, climatic conditions, year, and proportion of wood (Molina-Alcaide and Nefzaoui, 1996; Pertínez et al., 2000).

The CF content of the olive leaves decreased with SSF using $A$. niger, particularly in F3, which was capable of cellulase production, and in F4, 


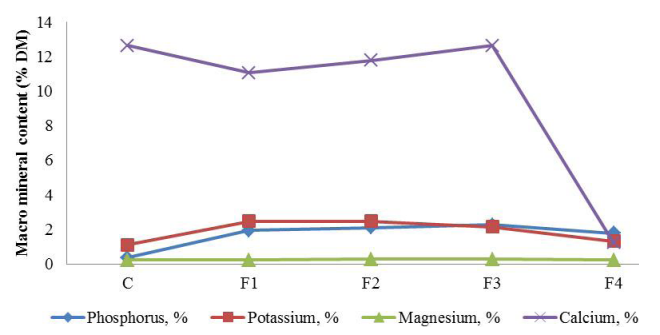

Figure 2. Changes in some of the macro mineral contents after solid state fermentation. C, unfermented olive leaves; F1, strain ATCC $^{\circledR} 9142^{\mathrm{TM}}$; F2, strain $\mathrm{ATCC}^{\circledR} 200345^{\mathrm{TM}}$; F3, strain ATCC $^{\circledR}$ 52172 ${ }^{\mathrm{TM}}$; and F4, strain $\mathrm{ATCC}^{\circledR} 201572^{\mathrm{TM}}$. The mineral analyses were performed on a single sample each time. Therefore, no statistical analyses were possible.

which was capable of cell protein production. The ability of $A$. niger cultures to produce cellulase has been observed in other Aspergillus sp., as well as in other microorganisms, namely, Chaetomium sp., Fusarium sp., Myrothecium sp., Trichoderma sp., and Penicillium sp. (Aguilar et al., 2008). A decrease in the CF content of tapioca bark was reported in another study using A. niger SSF (Aderemi and Nworgu, 2007), and this decrease was considered to be related to the hydrolytic nature of $A$. niger. This claim was supported by the work of Chesson (1993), who stated that certain enzymes released by the fungus during fermentation could break down cell walls. However, to observe such an effect, the physiochemical properties of both the substrate and enzyme need to be fully compatible. Thus, because the CF content decreased in all groups after fermentation, the $A$. niger strains used in the present study were compatible with olive leaves,

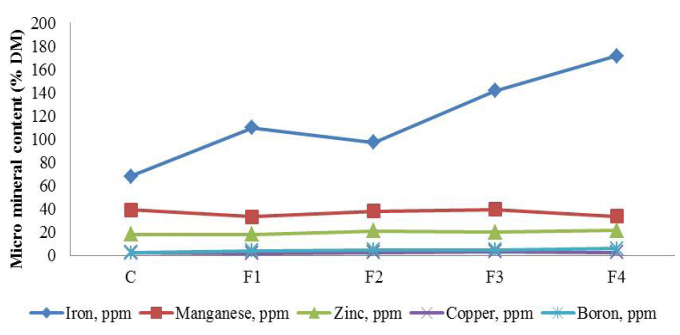

Figure 3. Changes in the contents of some of the micro minerals in olive leaves after solid state fermentation. C, unfermented olive leaves; F1, strain ATCC $^{\circledR} 9142^{\mathrm{TM}}$; F2, strain ATCC $^{\circledR} 200345^{\mathrm{TM}}$; F3, strain ATCC $^{\circledR} 52172^{\mathrm{TM}}$; and F4, strain ATCC $^{\circledR} 201572^{\mathrm{TM}}$. The mineral analyses were performed on a single sample each time. Therefore, no statistical analyses were possible.

and the breakdown of the cell walls was achieved, decreasing the leaf cellulose content. However, the decrease observed in the CF content with the F3 treatment was expected because the strain used in this group had the ability to break down cellulose. In fact, the cellulose content of the F3 olive leaves after fermentation was lower than that in the other groups, with the exception of F4.

The ADF content of the olive leaves significantly decreased with SSF, although to different extents in the different groups, but the NDF content was not significantly changed with fermentation. According to the in vitro study conducted by Pertínez et al. (2000) on olive leaf nutritional composition and digestibility, DM and organic matter digestibility decreased with increasing ADF and NDF contents. Researchers have also suggested that an increase in the NDF content could negatively affect protein digestibility, and similar findings were obtained

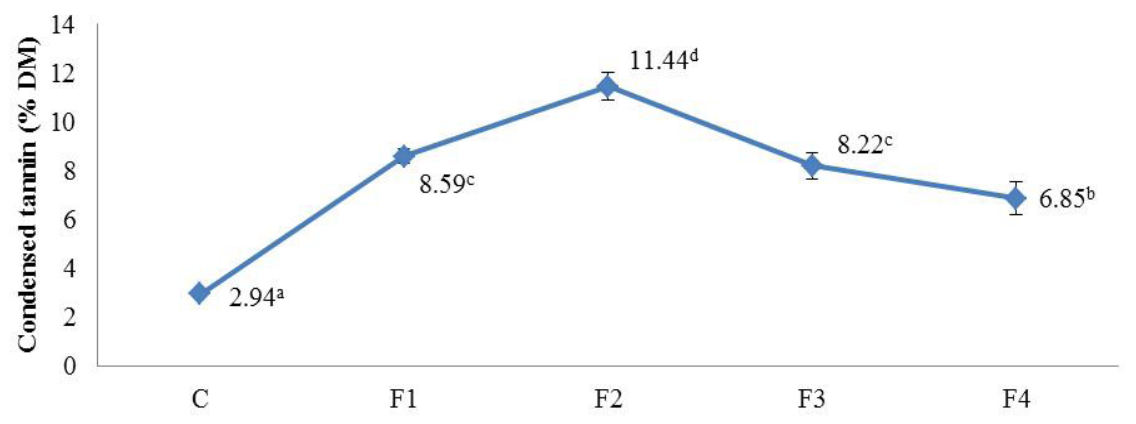

Figure 4. Condensed tannin contents in the fermented and unfermented olive leaves after solid state fermentation. C, unfermented olive leaves; F1, strain ATCC $^{\circledR} 9142^{\mathrm{TM}}$; F2, strain $\mathrm{ATCC}^{\circledR} 200345^{\mathrm{TM}}$; F3, strain $\mathrm{ATCC}^{\circledR} 52172^{\mathrm{TM}}$; and F4, strain $\mathrm{ATCC}^{\circledR} 201572^{\mathrm{TM}}$. Different superscripts in the same row indicate significant differences $(\mathrm{P}<0.05)$. 
in a digestibility study with olive cake (MartínGarcía et al., 2003). Although leaf digestibility was not measured in the present study, the ADF, NDF, and cellulose levels observed suggest that SSF might positively affect the digestibility of the fermented olive leaves. However, further studies need to be conducted to confirm this hypothesis. In addition, because ADF is a combination of cellulose and lignin and the cellulose content decreased in all groups after SSF, the idea that the microbial inoculants provided enzymes that could break down cellulosic structures was supported by the decrease in ADF.

In the present study, the starch and sugar contents in all groups except F1 irregularly decreased after fermentation $(\mathrm{P}<0.01)$. The decreases in the carbohydrate content of the fermented olive leaves could be related to the hydrolytic ability of the enzymes released by the microbial inoculants, which degrade leaf starch, providing glucose and glycosine that are then used by the microorganisms as carbon sources (Rai et al., 1988; Oboh, 2006). This hypothesis was supported by the decrease in the carbohydrate content of tapioca roots fermented using $A$. niger, which was accompanied by an increase in the protein content (Okpako et al., 2008). The researchers suggested that these changes could be due to the use of starches and sugars as carbon sources for microorganism development during SSF, thereby causing a decrease in the carbohydrate content of the fermented tapioca roots. Similar results were obtained by Aguilar et al. (2008) in their study on solid-state-fermented creosote bush leaves and pomegranate rind using $A$. niger. The results of the present study also corroborate this theory, as the starch and sugar contents decreased in most of the fermented olive leaves, while the protein content increased. The increase observed in the starch and sugar contents of F1 might be due to the sugars released from the hydrolysis of phenolic compounds during fermentation.

The protein content of the olive leaves at both the nitrogen level and amino acid level increased after fermentation, although to different extents according to the $A$. niger strain used; these results revealed that the properties of each strain influenced the SSF results. This theory was corroborated by the fact that F4, a group with the potential to produce single cell proteins, showed the highest increase in protein. The variations in the protein and amino acid contents among the different groups could be explained by the type and amount of enzymes released by the microorganisms. Oboh and Akindahunsi (2003) determined that the enzymes (protease, amylase, cellulase, hemicellulase, hydrolase, pectinase, etc.) released by microorganisms during fermentation in order to use vegetable materials (protein, starch, sugar, or cellulose) as carbon sources could increase the protein content of the fermented product (Mathivanan et al., 2006). On the other hand, some studies have shown that the increase in protein could be due to the increase in fungus mycelium resulting from the growth and reproduction of the microorganisms during fermentation (Oboh, 2006). Thus, the increase in the protein and amino acid contents of the fermented olive leaves observed in the present study might also be explained by the abovementioned factors.

The ash composition increased after fermentation, similar to that reported by Okpako et al. (2008) for fermented tapioca bark, by Oboh and Akindahunsi (2003), who used Saccharomyces cerevisiae as the microbial inoculant in SSF, and by Aguilar et al. (2008), who also used A. niger for the SSF of creosote bush leaves and pomegranate rinds. Most of the mineral contents, especially phosphorous, also increased after SSF. Rai et al. (1988) suggested that phosphorus in a complex state could be broken down by phytase released by fungus, and Dei et al. (2008) suggested that this enzyme released the phosphorus connected to it during fermentation, thereby increasing the phosphorus levels of the fermented product. In the present study, the increase in phosphorus observed in the fermented leaves might also be attributed to the release of phytase by $A$. niger during fermentation. On the other hand, the calcium content decreased 
with olive leaf fermentation, contrasting with the findings of Aderemi and Nworgu (2007), in which the calcium, potassium, and sodium contents increased in tapioca roots after SSF using $A$. niger.

Bacteria, yeasts, and filamentous fungi are known as tannase producers, and Aspergillus species are the best tannase-producing microorganisms during SSF (Bhat et al., 1998). Saxena et al. (1995) reported that Aspergillus sp. and Penicillium sp. could use catechin, gallotannin, and gallic acid as carbon sources. Because Aspergillus species can also produce enzymes such as hemicellulase, hydrolase, pectinase, and lipase during SSF, they can easily change the structure of anti-nutritional factors by using substrates such as polysaccharides and tannins (Hong et al., 2004). Scalbert (1991) suggested that hydrolyzed tannins were more resistant to microorganismal secretions than condensed tannins. Accordingly, Dei et al. (2008) stated that microorganisms could break down hydrolyzed tannins more easily than condensed tannins during SSF. Thus, in the present study, the condensed tannin content changed according to the ability of the $A$. niger strains to produce tannase and other enzymes. Nevertheless, because SSF using microorganisms is a rather new technique, further studies are necessary to determine the effects of the microbial inoculants involved in SSF on the production of tannins and its derivatives.
In conclusion, the current solid-state fermentation with $A$. niger strains used in this study increased the protein and amino acid contents of the olive leaves and decreased the cellulose and condensed tannin contents. The harvested olives mainly come to olive oil mills with their leaves. These leaves have not been used efficiently in any industry and cause environmental problems. Although the raw nutrient contents of olive leaves are suitable for native goat nutrition, the current SSF technique would allow olives leaves to be used for ruminants and for poultry due to the increased protein ( + amino acid) level and lowered crude fiber content. In addition, these findings will encourage animal nutritionists to use $A$. niger strains on other agricultural byproducts. Since the selected $A$. niger strains and olive leaves were compatible and the necessary environmental conditions for microorganismal reproduction were formed, a new direction for studies involving SSF was found.

\section{Acknowledgments}

The financial support from the Scientific and Technological Research Council of Turkey (project number TUBITAK-TOVAG 114R110) is gratefully appreciated.

\section{Resumen}

A. Altop, I. Coskun, G. Filik, A. Kucukgul, Y.G. Bekiroglu, H. Cayan, E. Gungor, A. Sahin, y G. Erener. 2018. Aminoácidos, minerales, taninos condensados y otros contenidos químicos en las hojas de olivo (Olea europaea $L_{\text {.) }}$ procesados mediante fermentación en estado sólido utilizando cepas seleccionadas de Aspergillus niger. Cien. Inv. Agr. 45(3): 220-230. El presente estudio tuvo como objetivo examinar los efectos de fermentación en estado sólido (FES) usando cepas de $A$. niger selectiva en el aminoácido, mineral, taninos condensados, y otros contenidos químicos de hojas de olivo. Las muestras secas se dividen en no fermentada (C) y se fermentan (F) hojas de olivo, y el último se fermentaron por las siguientes cepas de

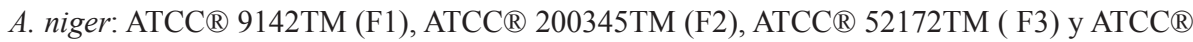
201572 TM (F4), con tres repeticiones cada uno. Grupo F4 presentó los mejores resultados, aunque todos los grupos fermentadas presentan generalmente un mayor rendimiento que $\mathrm{C}$. El contenido total de aminoácidos en hojas de olivo fermentados aumentó y 68 a 209\% en comparación con $\mathrm{C}$, mientras que el contenido de celulosa de hojas de olivo fermentados Disminución de 7-25\% . La ceniza, proteína bruta (CP) y el extracto de éter (EE) Aumento de 
contenidos después de la fermentación, pero la fibra bruta (FB) y extracto libre de nitrógeno (NFE) disminuyó. La fibra detergente neutra (NDF) no cambió pero la fibra detergente ácida (ADF) varió entre los grupos. El contenido de almidón y azúcar de todos los grupos fermentados, excepto F1, también disminuyó. El contenido mineral aumentó en todos los grupos fermentados y el contenido de tanino condensado de acuerdo con la cepa de $A$. niger utilizada. Por lo tanto, hojas de olivo fermentados con diferentes cepas de A. niger, especialmente F4, parecen tener una considerabl el potencial para la alimentación de los rumiantes, ya que están enriquecidas con minerales y amino ácidos, y presentar una composición química mejorada. Sin embargo, estos resultados deben ser apoyados y validados por experimentos con animales.

Palabras clave: Calidad nutricional, fermentación, hongos, Olea.

\section{References}

Aguilar, C.N., A. Aguilera-Carbo, and A. Robledo. 2008. Production of antioxidant nutraceuticals by solid-state cultures of pomegranate (Punica granatum) peel and creosote bush (Larrea tridentata) leaves. Food Technology and Biotechnology. 46:218-222.

Aderemi, F., and F. Nworgu. 2007. Nutritional status of cassava peels and root sieviate biodegraded with Aspergillus niger. American-Eurasian Journal Of Agriculture And Environment Science. 2:308-311.

AOAC. Official methods of analysis. 1990. Association of Official Analytical Chemists. 1:684.

Bhat, T.K., B. Singh, and O.P. Sharma. 1998. Microbial degradation of tannins-a current perspective. Biodegradation. 9:343-357.

Cayan, H., and G. Erener. 2015. Effect of olive leaf (Olea europaea) powder on laying hens performance, egg quality and egg yolk cholesterol levels. Asian-Australasian Journal of Animal Science. 28:4.

Chesson, A. 1993. Feed enzymes. Animal Feed Science And Technology. 45:65-79.

David, H., M. Åkesson, and J. Nielsen. 2003. Reconstruction of the central carbon metabolism of Aspergillus niger. European Journal of Biochemistry. 270:4243-4253.

Dei, H., S. Rose, A. Mackenzie, and R. Amarowicz. 2008. Growth performance of broiler chickens fed diets containing shea nut (Vitellaria paradoxa, Gaertn.) meal fermented with Aspergillus niger. Poultry Science. 87:1773-1778.
Dermeche, S., M. Nadour, C. Larroche, F. MoultiMati, and P. Michaud. 2013. Olive mill wastes: biochemical characterizations and valorization strategies. Process Biochemistry. 48:1532-1552.

Dimova, N. 2003. RP-HPLC analysis of amino acids with UV-detection. Comptes Rendus De l'Academie Bulgare Des Sciences. 56:12-75.

Hong, K.J., C.H. Lee, and S.W. Kim. 2004. Aspergillus oryzae GB-107 fermentation improves nutritional quality of food soybeans and feed soybean meals. Journal of Medicinal Food. 7:430-435

Makkar, H., M. Blümmel, and K. Becker. 1995. Formation of complexes between polyvinyl pyrrolidones or polyethylene glycols and tannins, and their implication in gas production and true digestibility in in vitro techniques. British Journal of Nutrition. 73:897-913.

Martín-García, A., and E. Molina-Alcaide. 2008. Effect of different drying procedures on the nutritive value of olive (Olea europaea var. europaea) leaves for ruminants. Animal Feed Science and Technology. 142: 317-329.

Martín-García, A., A. Moumen, D.Y. Ruiz, and E.M. Alcaide. 2003. Chemical composition and nutrients availability for goats and sheep of two-stage olive cake and olive leaves. Animal Feed Science and Technology. 107:61-74.

Mathivanan, R., P. Selvaraj, and K. Nanjappan. 2006. Feeding of fermented soybean meal on broiler performance. International Journal of Poultry Science. 5: 868-872.

Molina-Alcaide, E., and A. Nefzaoui. 1996. Recycling of olive oil by-products: possibilities 
of utilization in animal nutrition. International Biodeterioration and Biodegradation. 38:227-235.

Moran, J., and D. Jones. 1992. Maize silage for the pasture-fed dairy cow. A comparison between two systems for feeding silage while grazing perennial pastures in the spring. Australion Journal of Experimental Agriculture. 32:287-292.

Oboh, G. 2006. Nutrient enrichment of cassava peels using a mixed culture of Saccharomyces cerevisae and Lactobacillus spp. solid media fermentation techniques. Electronic Journal of Biotechnology. 9:1.

Oboh, G., and A. Akindahunsi. 2003. Biochemical changes in cassava products (flour \& gari) subjected to Saccharomyces cerevisiae solid media fermentation. Food Chemistry. 82:599-602.

Okpako, C., V. Ntui, A. Osuagwu, and F. Obasi. 2008. Proximate composition and cyanide content of cassava peels fermented with Aspergillus niger and Lactobacillus rhamnosus. Journal of Food Agriculture and Environment. 6:251.

Paiva-Martins, F., S. Barbosa, V. Pinheiro, J.L. Mourão, and D. Outor-Monteiro. 2009. The effect of olive leaves supplementation on the feed digestibility, growth performances of pigs and quality of pork meat. Meat Science. 82:438-443.

Pertínez, M.D., A. Gómez-Cabrera, and A. Garrido. 2000. Predicting the nutritive value of the olive leaf (Olea europaea): digestibility and chemical composition and in vitro studies. Animal Feed Science and Technology. 87:187-201.

Rai, S., K. Singh, B. Gupta, and T. Walli. 1988. Microbial conversion of crop residues with reference to its energy utilization by ruminants - an overview. Fibrous crop residues as animal feed, ICAR, New Delhi, pp. 66-74.

Robinson, P., D. Givens, and G. Getachew. 2004. Evaluation of NRC, UC Davis and ADAS approaches to estimate the metabolizable energy values of feeds at maintenance energy intake from equations utilizing chemical assays and in vitro determinations. Animal Feed Science and Technology. 114:75-90.

Sateri, S., A. Seidavi, M. Bouyeh, P. Neumann, M. Kutzler, V. Laudadio, F. Loperfido, and V. Tu- farelli. 2017. Effect of olive meal and supplemental enzymes on performance traits, blood biochemistry, humoral immunity response and caecal microbiota of broilers. South African Journal of Animal Science, 47(6):804-812.

Saxena, R., P. Sharmila, and V.P. Singh. 1995. Microbial degradation of tannins. Microbiology. 32:259-270.

Sayehban, P., A. Seidavi, M. Dadashbeiki, A. Ghorbani, W.A.G. Araújo, and L.F.T. Albino. 2015. Effects of different dietary levels of two types of olive pulp and exogenous enzyme supplementation on the gastrointestinal tract size, immunology and hematology of broilers. Revista Brasileira de Ciência Avícola, 17(SPE):73-85.

Sayehban, P., A. Seidavi, M. Dadashbeiki, A. Ghorbani, W.A.G. Araújo, and L.F.T. Albino. 2016. Effects of different levels of two types of olive pulp with or without exogenous enzyme supplementation on broiler performance and economic parameters. Revista Brasileira de Ciência Avícola, 18(3):489-500.

Scalbert, A. 1991. Antimicrobial properties of tannins. Phytochemistry. 30:3875-3883.

Xie, P., L. Huang, C. Zhang, and Y. Zhang. 2016. Nutrient assessment of olive leaf residues processed by solid-state fermentation as an innovative feedstuff additive. Journal of Applied Microbiology. 121:28-40.

Van Soest, P.V., J. Robertson, and B. Lewis. 1991. Methods for dietary fiber, neutral detergent fiber, and nonstarch polysaccharides in relation to animal nutrition. Journal of Dairy Science. 74:3583-3597.

Yao, W., and S.E. Nokes. 2014. First proof of concept of sustainable metabolite production from high solids fermentation of lignocellulosic biomass using a bacterial co-culture and cycling flush system. Bioresource Technology. 173:216-223.

Zhang, X., F. Cao, Z. Sun, W. Yu, L. Zhao, G. Wang, and T. Wang. 2012. Effect of feeding Aspergillus niger-fermented Ginkgo biloba leaves on growth, small intestinal structure and function of broiler chicks. Livestock Science. 147:170-180. 